University of Nebraska - Lincoln

DigitalCommons@University of Nebraska - Lincoln

USDA Wildlife Services - Staff Publications

U.S. Department of Agriculture: Animal and Plant Health Inspection Service

2017

\title{
Development of Toxic Bait to Control Invasive Wild Pigs and Reduce Damage
}

\author{
Nathan P. Snow \\ Texas A\&M University-Kingsville, nathan.p.snow@aphis.usda.gov \\ Justin A. Foster \\ Texas Parks and Wildlife Department \\ John C. Kinsey \\ Texas Parks and Wildlife Department \\ Simon T. Humphrys \\ Invasive Animals Cooperative Research Center \\ Linton D. Staples \\ Animal Control Technologies Australia Pty Ltd
}

See next page for additional authors

Follow this and additional works at: https://digitalcommons.unl.edu/icwdm_usdanwrc

Part of the Life Sciences Commons

Snow, Nathan P.; Foster, Justin A.; Kinsey, John C.; Humphrys, Simon T.; Staples, Linton D.; Hewitt, David G.; and VerCauteren, Kurt C., "Development of Toxic Bait to Control Invasive Wild Pigs and Reduce Damage" (2017). USDA Wildlife Services - Staff Publications. 1966.

https://digitalcommons.unl.edu/icwdm_usdanwrc/1966

This Article is brought to you for free and open access by the U.S. Department of Agriculture: Animal and Plant Health Inspection Service at DigitalCommons@University of Nebraska - Lincoln. It has been accepted for inclusion in USDA Wildlife Services - Staff Publications by an authorized administrator of DigitalCommons@University of Nebraska - Lincoln. 
Authors

Nathan P. Snow, Justin A. Foster, John C. Kinsey, Simon T. Humphrys, Linton D. Staples, David G. Hewitt, and Kurt C. VerCauteren 


\title{
Development of Toxic Bait to Control Invasive Wild Pigs and Reduce Damage
}

\author{
NATHAN P. SNOW iD, ${ }^{\mathbf{1 , 2}}$ Caesar Kleberg Wildlife Research Institute, Texas AङM University-Kingsville, 700 University Blvd., MSC 218, \\ Kingsville, TX 78363, USA \\ JUSTIN A. FOSTER, Kerr Wildlife Management Area, Texas Parks and Wildlife Department, 2625 FM 1340, Hunt, TX 78024, USA \\ JOHN C. KINSEY, Kerr Wildlife Management Area, Texas Parks and Wildlife Department, 2625 FM 1340, Hunt, TX 78024, USA \\ SIMON T. HUMPHRYS, Invasive Animals Cooperative Research Center, 33 Flemington St., Glenside, SA 5062, Australia \\ LINTON D. STAPLES, Animal Control Technologies Australia Pty Ltd, 46-50 Freight Dr., Somerton, Vic 3062, Australia \\ DAVID G. HEWITT, Caesar Kleberg Wildlife Research Institute, Texas AEM University-Kingsville, 700 University Blvd., MSC 218, Kingsville, \\ $T X 78363$, USA \\ KURT C. VerCAUTEREN, USDA/APHIS/ Wildife Services, National Wildlife Research Center, 4101 LaPorte Ave., Fort Collins, CO 80521, \\ $U S A$
}

\begin{abstract}
Populations of invasive wild pigs (Sus scrofa) are increasing in many regions of the world, in particular the United States and Australia. Invasive wild pigs cause extensive damage to ecological resources and agriculture. Development and registration of a safe and humane toxic bait offers a practical and costeffective tool to control invasive species. Currently, no toxicants are approved for use on invasive wild pigs in the United States and those approved in Australia are under scrutiny because of concerns regarding humaneness and effects on nontarget species. We tested a newly formulated bait containing the microencapsulated active ingredient, sodium nitrite $\left(\mathrm{HOGGONE}^{\mathbb{R}}\right.$; Animal Control Technologies Australia $\mathrm{P} / \mathrm{L}$, Victoria, Australia), that is considered humane and safer for nontarget species because it does not bioaccumulate. We examined palatability, lethality, and stability of the bait (i.e., fresh compared to 8-monthold bait) on groups of captive invasive wild pigs. We found HOGGONE ${ }^{\mathrm{B}}$ was a preferred food item, averaging $475 \mathrm{~g}$ of toxic bait consumed per animal during the first night offered. Consumption of HOGGONE ${ }^{\mathbb{R}}$ resulted in $95 \%$ mortality (53 of 56) in the treatment groups across 2 treatment nights. Most mortalities (98\%) occurred during the first night the toxic bait was offered. Camera evidence suggested that deaths occurred within $3 \mathrm{hr}$ post-offering. The toxic bait was stable and effective up to 8 months post manufacture. Our results support current applications to register HOGGONE ${ }^{\mathbb{R}}$ for reducing damage from invasive wild pigs in the United States and Australia. Further research is required to evaluate HOGGONE ${ }^{\circledR}$ on free-ranging invasive wild pigs using bait stations that exclude nontarget species. ( 2017 The Wildlife Society.
\end{abstract}

KEY WORDS feral swine, integrated pest management, pesticide, Sus scrofa, toxicant, wild boar, wildlife damage management.

Invasive wild pigs (Sus scrofa; hereafter: wild pigs), also termed feral hogs, feral pigs, feral swine, or wild boars (Keiter et al. 2016), are widely distributed and destructive throughout parts of North America, Australia, South America, Africa, and many island nations (Barrios-Garcia and Ballari 2012). Populations of wild pigs cause extensive agricultural, ecological, and control costs (Hone 1995, Pimentel et al. 2000, Pimentel 2007). Annual economic

Received: 2 February 2017; Accepted: 6 March 2017

Published: 27 June 2017

${ }^{1}$ E-mail: nathan.p.snow@aphis.usda.gov

${ }^{2}$ Current affiliation: USDA/APHIS/Wildlife Services, National Wildlife Research Center, 4101 LaPorte Ave., Fort Collins, Colorado 80521, USA. losses attributed to wild pigs have been estimated at US $\$ 1.5$ billion across the United States in crop damages and control costs (Pimentel 2007). Another estimate suggests US $\$ 190$ million of losses caused by wild pigs in crop yields per year throughout 10 high-producing states (Anderson et al. 2016). In addition, wild pigs are reservoirs and spread diseases (Hahn et al. 1997, Doran and Laffan 2005), damage native ecosystems and natural resources by reducing plant species diversity (Hone 2002), depredate sensitive species (Taylor and Hellgren 1997, Fordham et al. 2006, Jolley et al. 2010), and destroy habitats of desired native species (van Riper and Scott 2001).

Populations of wild pigs are increasing throughout the United States and Australia (West 2008, Bevins et al. 2014, Snow et al. 2017). These increases were attributed to 
intentional and accidental introductions by humans (Spencer and Hampton 2005, Barrios-Garcia and Ballari 2012), high reproductive potential (Mayer and Brisbin 2009), lack of predators (Bevins et al. 2014), and human alterations to the landscape that increased habitat availability and opportunity for wild pigs to feed (Seward et al. 2004). Local reductions in wild pig populations and associated damage have been achieved through trapping, snaring, recreational hunting, professional sharpshooting, and aerial shooting (Coblentz and Baber 1987, Choquenot et al. 1993, Mayer and Brisbin 2009, West et al. 2009, Campbell et al. 2010). Although locally effective, these methods are labor intensive and have not mitigated damage across large regions (Dickson et al. 2001, Adams et al. 2006). More cost effective tools are needed to better control existing populations of wild pigs and curtail their expansion and associated damage (Coblentz and Baber 1987, Sweeney et al. 2003).

Toxic baits offer a cost-effective option for controlling wild pigs, provided that appropriate safety, humaneness, and efficacy criteria are met (O'Brien 1986, Cowled et al. 2008). Only one toxic bait is registered for use on wild pigs in the United States (Kaput ${ }^{\mathbb{R}}$; Scimetrics Ltd. Corp., Wellington, CO, USA), a warfarin-based toxic bait, but has not been approved for use in any state. Two toxic baits containing the active ingredients sodium fluoroacetate (1080) or yellow phosphorus are approved for use on wild pigs in Australia. Both baits have generated concerns about humaneness and hazards for nontarget species (Cowled et al. 2008). Recently, a more humane and less hazardous chemical, sodium nitrite, has been proposed as a new active ingredient for a wild pig bait (Cowled et al. 2008, Lapidge et al. 2012, Shapiro et al. 2016).

Sodium nitrite is considered a humane toxicant because it causes severe methemoglobinemia, a rapid loss of consciousness followed by death from tissue hypoxia without a prolonged state of suffering (Institute of Medical and Veterinary Science 2010). Mortality was reported $<4 \mathrm{hr}$ post-ingestion of a lethal dose (Cowled et al. 2008).
Additionally, sodium nitrite has a reduced risk of secondary poisoning because it is metabolized quickly and generates little potential for bioaccumulation (Lapidge et al. 2012).

A collaborative research effort between the National Wildlife Research Center (NWRC) of the United States Department of Agriculture, Texas Parks and Wildlife Department (TPWD), Invasive Animal Cooperative Research Center (IACRC) in Australia, and Animal Control Technologies Australia (ACTA) has developed HOGGONE $^{\circledR}$ (ACTA, Victoria, Australia), an acutely toxic bait for wild pigs. HOGGONE ${ }^{\circledR}$ is comprised of $10 \%$ sodium nitrite. The sodium nitrite is specially preformulated using micro-encapsulation, and then manufactured into a blackcolored peanut paste and crushed-grain bait matrix (Snow et al. 2016). Micro-encapsulation of the sodium nitrite conceals its bitter taste from detection by wild pigs and stabilizes the reactive chemical.

Our study builds on previous research for developing an effective sodium nitrite toxic bait for wild pigs (Campbell et al. 2006, Cowled et al. 2008, Lapidge et al. 2012, Shapiro et al. 2016). Shapiro et al. (2016) recently tested a similar bait formulation to HOGGONE ${ }^{\mathbb{R}}$ in a pen and a field setting in nonreplicated experiments in New Zealand. Approximately $90 \%$ mortality was achieved in both settings, providing justification for further evaluation in the United States and Australia. Additionally, Shapiro et al. (2016) observed that the group feeding behaviors of wild pigs complicated toxicant delivery to all wild pigs. Invasive wild pigs are social animals (Gabor et al. 1999) usually living in groups of 3-9 individuals (Mayer 2009). In these groups, wild pigs exhibit interspecific feeding dominance and aggression (Mayer 2009), which likely affects consumption from localized food sources such as bait sites. Shapiro et al. (2016) observed that such behaviors may have reduced mortality in their study, suggesting further evaluation of baiting wild pigs in groups is needed. Finally, it is unknown how long HOGGONE ${ }^{\mathbb{R}}$ remains attractive and effective as

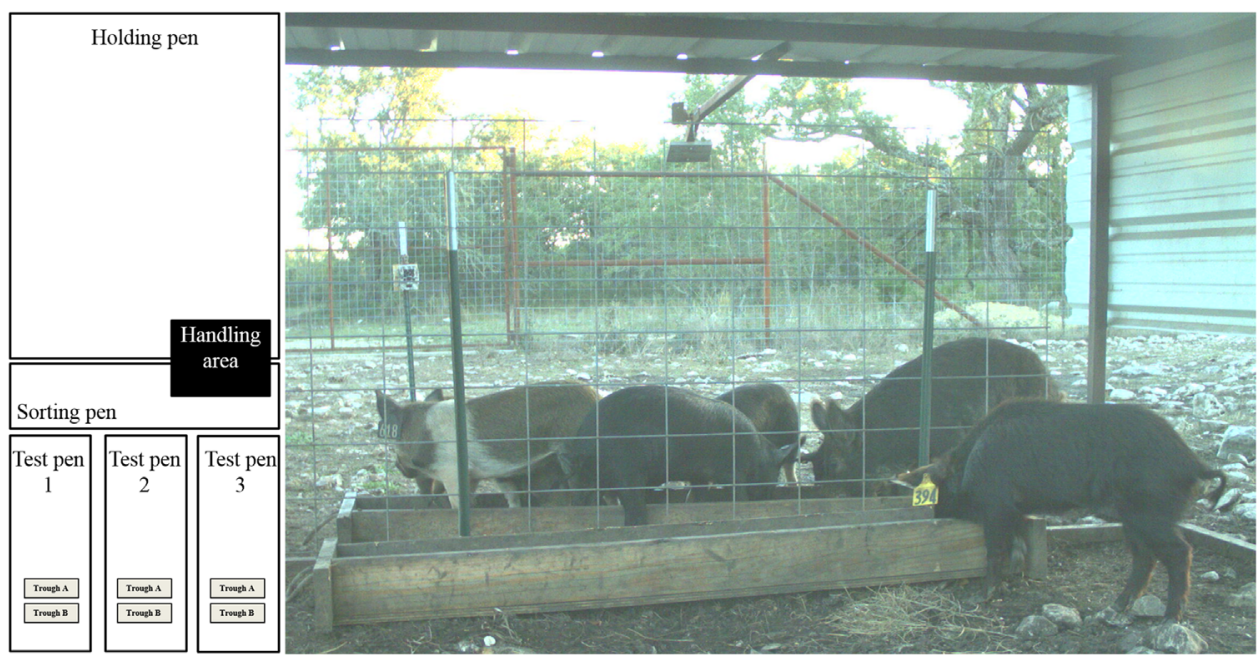

Figure 1. Configuration of trial pens and example photo for 2-choice trials designed to test the efficacy of HOGGONE ${ }^{\circledR}$ toxic bait on groups of 7 invasive wild pigs at the Kerr Wildlife Management Area, Hunt, Texas, USA during October 2015 to June 2016. The holding pen was $0.02 \mathrm{~km}^{2}$ and trial pens were each $0.002 \mathrm{~km}^{2}$. Two identical troughs per pen were separated by wire mesh fencing and we observed feeding bouts for each trough using motion activated cameras. 
a toxic bait for wild pigs given possible degradation of sodium nitrite over time.

Our primary objective was to determine the lethality and palatability using single bait sites with groups of captive wild pigs in a semi-controlled setting (i.e., outdoor pens) for HOGGONE ${ }^{\circledR}$, with an alternative food source available. Our secondary objective was to test the stability of HOGGONE ${ }^{\mathbb{R}}$ by examining efficacy of bait after being stored for 8 months.

\section{METHODS}

\section{Test Conditions}

We conducted testing during October 2015 to June 2016. Wild pigs used to conduct this test were group housed in a $0.02-\mathrm{km}^{2}$ outdoor holding pen at Kerr Wildlife Management Area (WMA), Hunt, Texas, USA, for $\geq 2$ weeks prior to study initiation (Fig. 1). The holding pen contained naturally growing vegetation on the ground, trees, and shade structures. Pens were constructed with steel mesh fencing buried into the ground to hold wild pigs.

We maintained the wild pigs on Bluebonnet ${ }^{\circledR} 18 \%$ Sow Ration Pellet (AC Nutrition, LP, Ardmore, OK, USA) provided at $3-5 \%$ of group body mass daily. This maintenance diet had a recommended feeding rate of 3\% of body weight for growing swine. We provided water $a d$ libitum in self-maintaining water troughs. We tested the water quality (National Testing Laboratories, Ltd., Cleveland, OH, USA) and did not detect contaminants above reference standards. The toxic HOGGONE ${ }^{\mathbb{B}}$ bait was manufactured on 2 October 2015 and stored indoors at ambient temperature and humidity after delivery to the Kerr WMA facilities until used.

Prior to each trial, we moved the wild pigs into a sorting chute and randomly selected 7 animals for each of 3 trial pens of $0.002 \mathrm{~km}^{2}$ (Fig. 1). We used 7 animals to be representative of typical group sizes in the wild (e.g., average $=3-9$ animals; Mayer 2009). We used the following conditions to randomly assign wild pigs into groups: 1) sex ratio for each trial was 4:3 females to males for consistency within the pens; and 2) animal masses were between $20 \mathrm{~kg}$ and $113 \mathrm{~kg}$ to ensure that dependent animals (i.e., piglets) were not included as independent samples and for safety of the researchers. We excluded any animals weighing $\geq 50 \mathrm{~kg}$ that were not deemed safe for handling (e.g., highly aggressive disposition). We moved the selected wild pigs into their respective pens for the trials. Daily temperatures during the study ranged from $-3.8^{\circ} \mathrm{C}$ to $32.2^{\circ} \mathrm{C}$ and precipitation ranged from $0.0 \mathrm{~cm}$ to $4.0 \mathrm{~cm}$.

All test pens were outdoors and subject to natural climatic conditions. These pens contained naturally growing vegetation on the ground, trees, and shade structures. Pens were immediately adjacent to each other so that all wild pigs experienced the same conditions (Fig. 1). Each pen was identically equipped with 2 feeding troughs (approx. $1.8 \times 0.3 \times 0.1 \mathrm{~m}$ ) that were fitted back to back, separated by a wire mesh panel, and covered with a structure to protect feed from direct precipitation. We uniformly distributed food items along the length of the trough to allow feeding by multiple wild pigs at one time. We selected the alternate food item, rough rice (i.e., seed rice; Oryza sativa), as the challenge diet for the 2-choice test portion of the study because wild pigs demonstrated a similar preference for rough rice as the placebo HOGGONE ${ }^{\circledR}$ (Blass et al. 2016).

\section{Study Design}

Each replicate trial consisted of 3 pens containing 7 wild pigs per pen. We conducted a total of 4 replicate trials. We conducted the first 3 replicate trials while the HOGGONE ${ }^{\circledR}$ was 1-2 months post-manufacture. We used these replicates to accomplish a complete experimental design where each pen contained 1 replicate of control animals. Specifically for the first replicate trial, we randomly assigned the trial pens as 2 toxicant pens and 1 control pen. We then rotated the toxic bait and control treatments in a randomized block design for the subsequent replicate trials of the study to control for any possible confounding effects from the individual pens. We conducted the fourth replicate trial approximately 8 months post-manufacture.

Each replicated trial lasted 8 nights. During nights 1 and 2, we allowed the wild pigs to acclimate to their new pens and fed them their regular maintenance diet at a minimal maintenance ration of $1 \%$ of group body mass, equally split between the 2 troughs. During nights 3-6, we pre-baited the wild pigs with the placebo bait at $1 \%$ of group body mass split equally between the 2 feeding troughs. During night 7 , we fed the wild pigs HOGGONE ${ }^{\circledR}$ toxic bait in the toxictreated pens and placebo bait in the control pens at 1.74\% of group body mass in a randomly assigned trough. In the opposite trough, we offered the challenge diet at $1.74 \%$ of group body mass (i.e., 2-choice trial period). During night 8, we fed any surviving wild pigs identical rations as night 7 (i.e., $1.74 \%$ of group body mass) except we switched baits and challenge diets to the opposite troughs to account for any possible confounding effects of individual troughs. Finally, we humanely euthanized any wild pigs that survived nights 7 and 8 via cranial gunshot following American Veterinary Medical Association guidelines on day 9 (Leary et al. 2013). We left all pens vacant for $\geq 7$ days between replicate trials to allow any residual scents and bait to dissipate naturally. For the fourth replicate (8-month-old bait), we shortened the prebaiting with placebo period by 1 day to avoid testing during inclement weather. All study activities were approved by the TPWD Institutional Animal Care and Use Committee (protocol no. 211072020151).

\section{Observations}

We fed the wild pigs each evening approximately $30 \mathrm{~min}$ before sunset, and checked the pens the next morning approximately $30 \mathrm{~min}$ after sunrise. We recorded the amount of food consumed during the night by removing and weighing any remaining food in the troughs and dropped food in the immediate area during the morning check. We calculated the average amount of consumption per individual by dividing the total amount consumed by the number of wild pigs in each pen. We recorded the number of mortalities in each pen during morning checks. We recorded post-trial 
weights and age classification of wild pigs via tooth eruption for each animal, except during the fourth replicate (Matschke 1967). Sub-adults were $>2$ months and $<1$ year, and adults were $>1$ year.

For the first 3 replicates, we used motion-activated cameras (Reconyx PC900, Holmen, WI, USA) to record feeding events and behavior at each trough during nights 68 for each trial. This allowed examination of feeding during the last night of pre-baiting and during the 2-choice nights. We mounted the cameras approximately $3 \mathrm{~m}$ away from troughs and 1-m high on steel T-posts. We set the cameras to record 30 picture bursts at 2-s intervals per motionactivated trigger, without a delay between bursts if triggered. We examined each image using the Colorado Parks and Wildlife Photo Database (v3.0) for image processing (Ivan and Newkirk 2015). We identified individual animals by ear tags or natural characteristics. We recorded which animals had their head directly above or in the trough to indicate feeding. We recorded feeding times and durations for each individual. We considered independent feeding bouts for each animal as feeding events separated by $\geq 30$ min of non-feeding activity.

We subsampled the HOGGONE ${ }^{\mathbb{R}}$ toxic bait used in the first 3 replicate trials to ensure consistent concentrations of sodium nitrite throughout the bait. For each replicate, we extracted 3, approximately $10-\mathrm{g}$ samples stratified from within 1 bucket of HOGGONE ${ }^{\circledR}$ including the top, middle, and bottom portions (i.e., 9 samples total). We also extracted 1 sample from the placebo bait during each replicate to ensure it did not contain sodium nitrite. We shipped the samples to the United States Department of Agriculture, National Wildlife Research Center (NWRC), Fort Collins, CO, USA for analysis of the concentration of sodium nitrite with a validated enforcement analytical method for HOGGONE ${ }^{\circledR}$ using reverse-phase-ion-chromatography (Method 180A, NWRC unpublished report). This method was validated using samples containing 1-15\% sodium nitrite. The efficiency of recovery for sodium nitrite averaged $92 \% \quad(\mathrm{SD}=2.4 \%)$ and the method limit of detection was $0.00036 \%$.

\section{Statistical Analyses}

We compared the proportion of bait and challenge diets consumed between the treatment and control groups using a multivariate generalized linear mixed-effects model. We compared the pre- and post-trial weights of groups using a linear mixed-effects model. We used a similar model to examine whether the proportion of HOGGONE ${ }^{\circledR}$ bait consumed was influenced by group body mass during the first night offered. We did not conduct a similar analysis for the second night because of a reduction in sample size in the HOGGONE ${ }^{\circledR}$ treatment group. For all mixed-effects models, we treated pens and treatment nights (first and second) as random effects.

We used a simple computation of the proportion of wild pigs (all individuals, males, females) that died across the 2 nights in the HOGGONE ${ }^{\circledR}$ treatment group as the metric of efficacy for HOGGONE ${ }^{\circledR}$. For the HOGGONE ${ }^{\circledR}$ treatment group, we compared its efficacy for males compared to females using a 2-tailed Fisher's exact test. We also compared mortality rates over the duration of the 2-choice trials between the toxic bait and control treatment groups as a whole and for females and males separately using 2-tailed Fisher's exact tests.

From camera data, we compared the number and length of feeding bouts between treatment and control animals, and between the challenge diet and HOGGONE ${ }^{\circledR}$ or placebo bait using multivariate generalized linear mixed-effects models. Within the HOGGONE ${ }^{\mathbb{R}}$ treatment group, we also compared the length and number of feeding bouts between wild pigs that died and did not die using multivariate generalized linear mixed-effects models. Again, we treated pens and treatment nights (first and second) as random effects for all mixed-effects models.

We ran the mixed-effects models using package lme4 in Program R (v3.1.1; R Foundation for Statistical Computing, Vienna, Austria). We performed Fisher's exact tests using Program R. For all statistical tests, we considered significant differences at the level of $\alpha=0.05$ or where $95 \%$ confidence intervals for parameter (fixed effect) estimates did not overlap 0 .

\section{RESULTS}

We used 84 wild pigs in our tests $\left(n=56\right.$ HOGGONE $^{\circledR}$ treatment animals and $n=28$ control animals). Of the 63 animals in the first 3 replicates, 28 were adults and 35 were sub-adults. Mortalities in the HOGGONE ${ }^{\circledR}$ treatment group were greater than in the control group $(P<0.001$; Table 1). The proportion of mortalities for males and females did not differ in the HOGGONE ${ }^{\circledR}$ treatment group $(P=0.25$; Table 1). We found 52 of 53 (98\%) of mortalities in the HOGGONE ${ }^{\circledR}$ treatment group occurred during the first night the toxic bait was offered. One of the 4 surviving wild pigs in the HOGGONE ${ }^{\mathbb{R}}$ treatment group consumed

Table 1. Sample sizes, proportions of food items consumed, and overall proportions of lethality for 2 treatment groups of invasive male (M) and female (F) wild pigs in 2-choice trials in 0.002-km² pens at Kerr Wildlife Management Area, Hunt, Texas, USA, during October 2015 to June 2016.

\begin{tabular}{|c|c|c|c|c|c|c|c|c|}
\hline \multirow[b]{2}{*}{$\begin{array}{l}\text { Treatment } \\
\text { group }\end{array}$} & \multirow[b]{2}{*}{$n(\mathrm{M}, \mathrm{F})$} & \multirow{2}{*}{$\begin{array}{c}\text { Days 1-2 } \\
\begin{array}{c}\text { Maintenance food } \\
\text { consumed }\end{array}\end{array}$} & \multirow{2}{*}{$\begin{array}{c}\text { Days 3-6 } \\
\begin{array}{c}\text { Placebo prebait } \\
\text { consumed }\end{array}\end{array}$} & \multicolumn{4}{|c|}{ Days 7-8 } & \multirow[b]{2}{*}{$\begin{array}{l}\text { Lethality } \\
(\mathrm{M}, \mathrm{F})\end{array}$} \\
\hline & & & & $\begin{array}{l}\text { HOGGONE }^{\circledR} \text { or } \\
\text { placebo consumed }\end{array}$ & SE & $\begin{array}{l}\text { Challenge diet } \\
\text { consumed }\end{array}$ & SE & \\
\hline $\mathrm{HOGGONE}^{\circledR}$ & $56(24,32)$ & 1.00 & 1.00 & 0.62 & 0.11 & 0.26 & 0.12 & $\begin{array}{c}0.95 \\
(1.00,0.91)\end{array}$ \\
\hline $\begin{array}{l}\text { Placebo } \\
\quad \text { (control) }\end{array}$ & $28(12,16)$ & 1.00 & 1.00 & 1.00 & 0.00 & 1.00 & 0.00 & $\begin{array}{c}0.00 \\
(0.00,0.00)\end{array}$ \\
\hline
\end{tabular}


HOGGONE $^{\circledR}$ and died on the second night. No individuals died in the control group on either night.

The HOGGONE ${ }^{\mathbb{R}}$ treatment group consumed a lower proportion of $\mathrm{HOGGONE}^{\circledR}$ than the control group consumed of placebo bait $(\beta=-0.42,95 \% \mathrm{CI}=-0.61$ to -0.17 ; Table 1) because the animals succumbed in the treatment group. Similarly, the HOGGONE ${ }^{\mathbb{B}}$ treatment group consumed lower proportions of the challenge diet than did the control group $(\beta=-0.77,95 \% \mathrm{CI}=-1.07$ to $-0.50)$. The proportion of HOGGONE ${ }^{\circledR}$ bait consumed was not influenced by group body mass ( $\beta=-0.001,95 \%$ $\mathrm{CI}=-0.003$ to 0.001 ). On average, individual wild pigs consumed approximately $479 \mathrm{~g} / \mathrm{animal}$ of HOGGONE ${ }^{\mathbb{R}}$ during the first night offered, but survivors only consumed an average of $56 \mathrm{~g} /$ animal during the second night (Fig. 2). The HOGGONE $^{\circledR}$ treatment animals consumed an average of $16.0 \mathrm{~g} / \mathrm{kg}$ body weight $(\mathrm{SE}=1.2)$ of $\mathrm{HOGGONE}^{\mathbb{R}}$ per night.

Analyses of images from motion-activated cameras indicated that HOGGONE ${ }^{\mathbb{R}}$ treatment animals underwent fewer feeding bouts on HOGGONE ${ }^{\circledR}$ than control animals on placebo $\mathrm{HOGGONE}^{\circledR}$ during the first night HOGGONE $^{\circledR}$ was offered $(\beta=-1.74,95 \% \mathrm{CI}=-2.20$ to -1.28 ) but not during the second night when only 4 survivors remained in the HOGGONE ${ }^{\mathbb{R}}$ treatment group ( $\beta=-0.66,95 \% \mathrm{CI}=-3.19$ to 1.99 ; Fig. 3 ). Similarly, the HOGGONE $^{\circledR}$ treatment group also had shorter feeding bouts than the control group during the first night toxic bait was offered ( $\beta=-25.45,95 \% \mathrm{CI}=-40.54$ to -10.37$)$ but not during the second night $(\beta=-23.93,95 \% \mathrm{CI}=-50.93$ to 10.89; Fig. 4).

Most of the feeding bouts for the HOGGONE ${ }^{\circledR}$ treatment groups occurred within $3 \mathrm{hr}$ post-offering of baits (Fig. 5). Only 4 wild pigs in the HOGGONE ${ }^{\circledR}$ treatment group survived the first night of exposure. Comparisons between those animals and non-survivors indicated that the survivors underwent more feeding bouts $(\beta=0.47,95 \% \mathrm{CI}$ $=0.70-0.25)$ but had similar durations of feeding $(\beta=0.58,95 \% \mathrm{CI}=-9.21$ to 10.38$)$ on $\mathrm{HOGGONE}^{\mathbb{R}}$ during the first night offered. Feeding bouts in the control

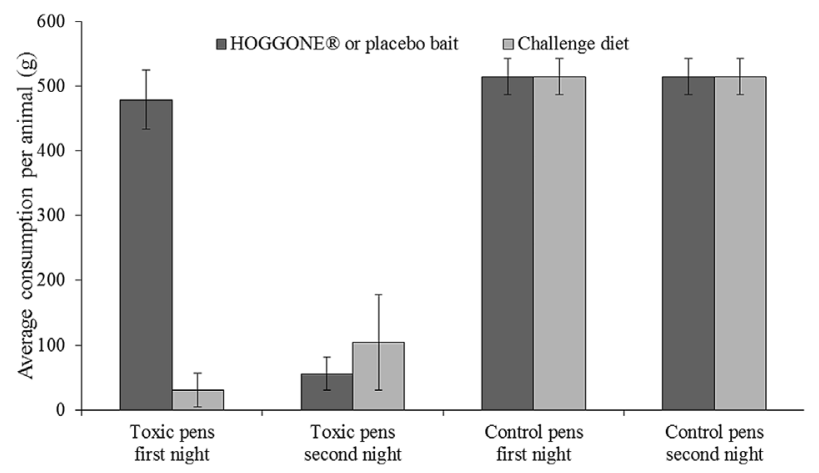

Figure 2. Average consumption (with SE) of baits $\left(\mathrm{HOGGONE}^{\circledR}\right.$ and placebo) and challenge diets consumed per invasive wild pig housed in groups of 7 animals in $0.002-\mathrm{km}^{2}$ pens during 2 consecutive nights of 2choice trial periods at the Kerr Wildlife Management Area, Hunt, Texas, USA, during October 2015 to June 2016.

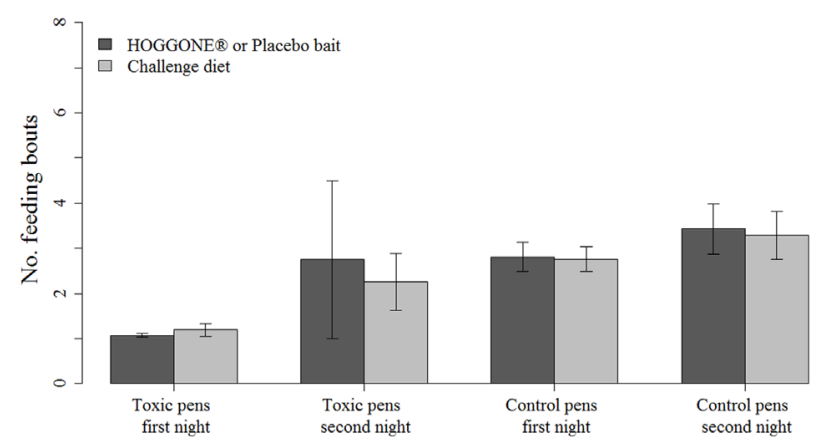

Figure 3. Mean number of feeding bouts (with SE) per invasive wild pig in HOGGONE ${ }^{\circledR}$ treatment (toxic bait) and control (placebo bait) groups in $0.002-\mathrm{km}^{2}$ pens during 2 consecutive nights of 2-choice trial periods at the Kerr Wildlife Management Area, Hunt, Texas, USA, during October 2015 to June 2016.

groups continued throughout the night but steadily decreased as the available food diminished.

Animals in the first 3 replicates lost some mass during the trial $(\bar{x}=-0.08$ proportion of body mass, $\mathrm{SD}=0.06)$, but mass loss did not differ between the treatment and control groups ( $\beta=0.03,95 \% \mathrm{CI}=-0.001$ to 0.06$)$ and none of the animals were emaciated post-trial. The average concentration of sodium nitrite in HOGGONE $^{\mathrm{R}}$ was $9.5 \%$ $(\mathrm{SD}=0.02)$, suggesting an actual concentration of $10.3 \%$, including the $8 \%$ recovery loss reported for the analytical method. All placebo samples contained $<0.01 \%$ sodium nitrite.

\section{DISCUSSION}

We found that HOGGONE ${ }^{\circledR}$ was a highly effective and acute toxic bait for groups of captive wild pigs in outdoor pens, generating $95 \%$ mortality. There was little evidence that feeding dominance among wild pigs reduced the efficacy of HOGGONE ${ }^{\circledR}$, given that $100 \%$ of the wild pigs died in 4 of the 6 groups tested. Our rate of lethality was slightly greater than the pen and field tests in New Zealand using a similar bait formulation, but within the estimated confidence limits of those experiments (Shapiro et al. 2016). Combined,

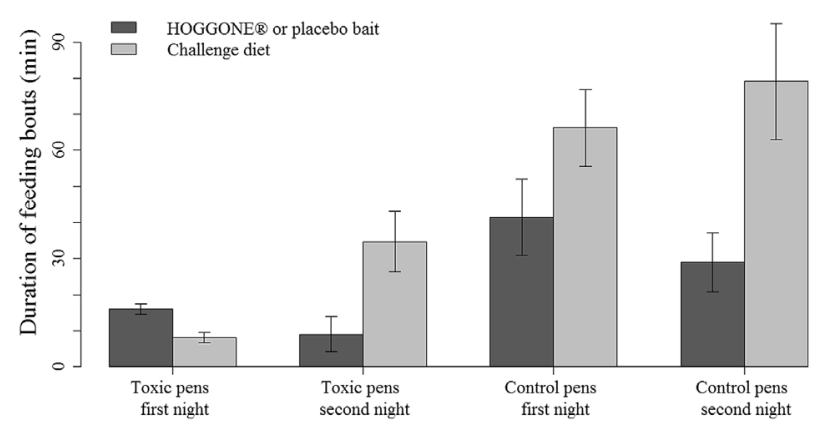

Figure 4. Mean duration of feeding bouts (with SE) per invasive wild pig in HOGGONE ${ }^{\circledR}$ treatment (toxic bait) and control (placebo bait) groups in $0.002-\mathrm{km}^{2}$ pens during 2 consecutive nights of 2 -choice trial periods at the Kerr Wildlife Management Area, Hunt, Texas, USA, during October 2015 to June 2016. 


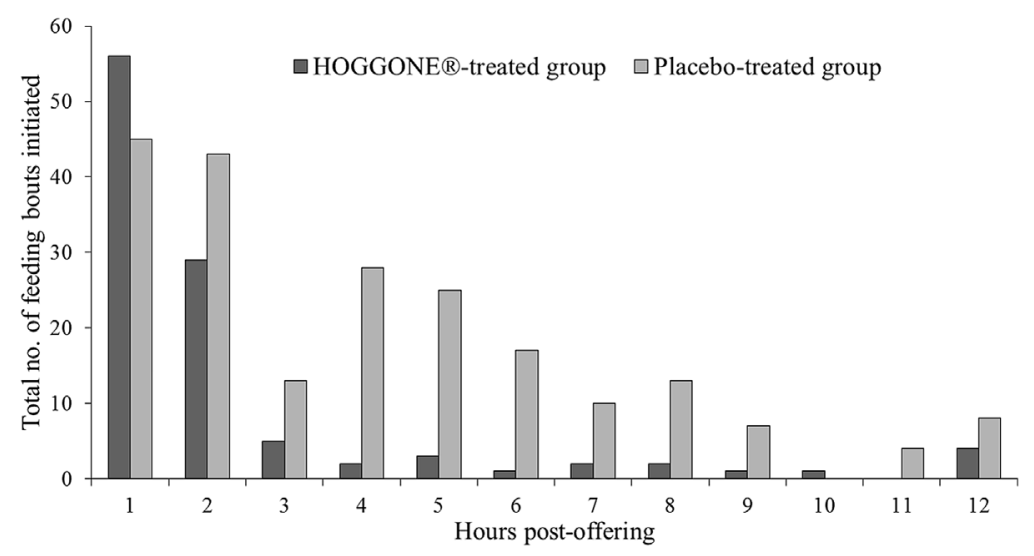

Figure 5. Count of feeding bouts per hour post-offering of HOGGONE ${ }^{\circledR}$ for invasive wild pigs in $0.002-\mathrm{km}^{2}$ pens during 2 consecutive nights of 2 -choice trial periods at the Kerr Wildlife Management Area, Hunt, Texas, USA, during October 2015 to June 2016.

these results suggest that individual and social groups of wild pigs are highly susceptible to HOGGONE ${ }^{\mathbb{R}}$.

HOGGONE ${ }^{\mathbb{R}}$ induced rapid mortality for wild pigs. Approximately $98 \%$ of the animals died within the first night, and camera image evidence suggests that most died within $3 \mathrm{hr}$ after the toxic bait was offered. These results comply with previously reported times-to-death from sodium nitrite with domestic and wild pigs(Cowled et al. 2008, Shapiro et al. 2016). Importantly, the quick times-todeath indicated that sufficient quantities of sodium nitrite were consumed in short duration and thereby quickly induced irreversible and fatal methemoglobinemia. These results corroborate that quick and lethal doses of sodium nitrite produce a state of unconsciousness without a prolonged preliminary period of distress and thereby support the conclusion that sodium nitrite is a humane toxicant for wild pigs (Cowled et al. 2008, Lapidge et al. 2009, Porter and Kuchel 2009). Other toxicants used in Australia were reported to be slower acting, including $2 \mathrm{hr}-5$ days for sodium monofluoroacetate (Hone and Kleba 1984, O'Brien 1988), 2-4 days for yellow phosphorous (O'Brien and Lukins 1990), and 6-10 days for warfarin (Hone and Kleba 1984, O'Brien 1988, O'Brien and Lukins 1990).

HOGGONE $^{\circledR}$ appeared to be highly palatable to wild pigs. The toxic bait was consumed more than the challenge diet in the treatment pens. It also appeared that most wild pigs consumed a lethal dose of HOGGONE ${ }^{\circledR}$ during a single feeding bout that lasted an average of $15 \mathrm{~min}$. During this time, wild pigs consumed an average of $16 \mathrm{~g} / \mathrm{kg}$ body weight of the $10 \%$ concentrated HOGGONE ${ }^{\mathbb{R}}$, which equates to $1,600 \mathrm{mg} / \mathrm{kg}$ of sodium nitrite, or approximately 4 times the reported lethal dose of sodium nitrite needed for wild pigs ( $400 \mathrm{mg} / \mathrm{kg}$; Cowled et al. 2008). Vigorous consumption of HOGGONE ${ }^{\circledR}$ is critical for inducing fatal methemoglobinemia, otherwise sub-lethal doses of sodium nitrite would be metabolized and allow the animal to recover. In addition, the toxic HOGGONE ${ }^{\circledR}$ bait remained palatable after being stored at ambient temperature and humidity for 8 months. This indicated that the microencapsulation coating remained intact to keep the bitter tasting sodium nitrite concealed during this time and protected the bait matrix from adverse interactions with sodium nitrite.

For the 3 wild pigs that survived both nights of HOGGONE ${ }^{\circledR}$ exposure, we found unconsumed HOGGONE $^{\circledR}$ remaining in the pens each night averaging $21.5 \mathrm{~g} / \mathrm{kg}$ body weight, confirming that bait was in excess at the selected application rate. Reasons why those animals survived exposure to HOGGONE ${ }^{\circledR}$ are unclear, but are consistent with previous examinations that not all wild pigs consumed lethal doses (Cowled et al. 2008, Shapiro et al. 2016). Notably, for the single animal that died during the second night of toxic baiting, we found $975 \mathrm{~g}$ of uneaten HOGGONE ${ }^{\circledR}$ during the first night of exposure. Although we observed this animal feeding during the first night, it showed no symptoms of sodium nitrite toxicity the subsequent morning and then consumed $101 \mathrm{~g}$ of HOG$\operatorname{GONE}^{\mathbb{R}}(2.25 \mathrm{~g} / \mathrm{kg}$ body weight $)$ during the second night and succumbed. This observation suggests that aversion to HOGGONE ${ }^{\circledR}$ from consuming a sub-lethal dose did not occur for this animal, which may be important for field applications.

An important and unintentional outcome from this study came from an unintended exposure of wild pig neonates to HOGGONE $^{\circledR}$. Four neonates weighing $1.3-1.8 \mathrm{~kg}$ (i.e., $<4$ weeks old) entered a treatment pen by squeezing through the wire mesh fencing and consumed the toxic HOGGONE ${ }^{\circledR}$ bait along with the group of randomly selected treatment animals. All of the wild pigs including the neonates succumbed to the toxic bait during the first night offered, providing evidence that all age classes of wild pigs are susceptible to HOGGONE ${ }^{\circledR}$.

\section{MANAGEMENT IMPLICATIONS}

Our results indicated that $\mathrm{HOGGONE}^{\circledR}$ is a promising new tool to assist in the large-scale control of invasive wild pigs. The bait proved lethal, acutely acting, and stable. Results from this study will be used to support the currently submitted application for an Experimental Use Permit to test HOGGONE $^{\circledR}$ in the field, and eventually for registering 
HOGGONE ${ }^{\circledR}$ for controlling wild pigs in the United States and in Australia. The next steps for registering HOG$\mathrm{GONE}^{\mathrm{R}}$ include the development of a bait station that excludes nontarget species, evaluation of lethality for freeranging wild pigs, and examination for any potential nontarget risks posed by carcasses of wild pigs that have succumbed to sodium nitrite.

\section{ACKNOWLEDGMENTS}

We thank C. Blass, J. Halseth, M. Lavelle, and J. C. Martin for assisting with data collection. We thank B. Hall and T. Larosa from Animal Control Technologies P/L for producing and shipping test materials. Test subjects were provided by the United States Department of Agriculture, Animal Plant and Health Inspection Service, Wildlife Services in Texas. E. Newkirk provided technical support with the CPW photo database. L. Greiner provided quality assurance for Good Laboratory Practices procedures. We thank anonymous reviewers for their comments on this manuscript. Mention of commercial products or companies does not represent an endorsement by the U.S. government.

\section{LITERATURE CITED}

Adams, C. E., K. J. Lindsey, and S. J. Ash. 2006. Urban wildlife management. CRC Press, Boca Raton, Florida, USA.

Anderson, A., C. Slootmaker, E. Harper, J. Holderieath, and S. A. Shwiff. 2016. Economic estimates of feral swine damage and control in 11 US states. Crop Protection 89:89-94.

Barrios-Garcia, M. N., and S. A. Ballari. 2012. Impact of wild boar (Sus scrof $a$ ) in its introduced and native range: a review. Biological Invasions 14:2283-2300.

Bevins, S. N., K. Pedersen, M. W. Lutman, T. Gidlewski, and T. J. Deliberto. 2014. Consequences associated with the recent range expansion of nonnative feral swine. BioScience 64:291-299.

Blass, C. R., N. P. Snow, J. C. Kinsey, J. A. Foster, and K. C. VerCauteren. 2016. Evaluation of potential food items as challenge diets in 2-choice tests with feral swine. Proceedings of the Vertebrate Pest Conference 27: in press.

Campbell, T. A., J. A. Foster, M. J. Bodenchuk, J. D. Eisemann, L. Staples, and S. J. Lapidge. 2013. Effectiveness and target-specificity of a novel design of food dispenser to deliver a toxin to feral swine in the United States. International Journal of Pest Management 59:197-204.

Campbell, T. A., S. J. Lapidge, and D. B. Long. 2006. Using baits to deliver pharmaceuticals to feral swine in southern Texas. Wildlife Society Bulletin 34:1184-1189.

Campbell, T. A., D. B. Long, and B. R. Leland. 2010. Feral swine behavior relative to aerial gunning in southern Texas. Journal of Wildlife Management 74:337-341.

Choquenot, D., R. J. Kilgour, and B. S. Lukins. 1993. An evaluation of feral pig trapping. Wildlife Research 20:15-21.

Coblentz, B., and D. Baber. 1987. Biology and control of feral pigs on Isla Santiago, Galapagos, Ecuador. Journal of Applied Ecology 24:403-418.

Cowled, B. D., P. Elsworth, and S. J. Lapidge. 2008. Additional toxins for feral pig (Sus scrofa) control: identifying and testing Achilles' heels. Wildlife Research 35:651-662.

Dickson, J. G., J. J. Mayer, and J. D. Dickson. 2001. Wild hogs. Pages 191-208 in J. G. Dickson, editor. Wildlife of southern forests: habitat and management. Hancock House Publishers, Blaine, Washington, USA.

Doran, R. J., and S. W. Laffan. 2005. Simulating the spatial dynamics of foot and mouth disease outbreaks in feral pigs and livestock in Queensland, Australia, using a susceptible-infected-recovered cellular automata model. Preventive Veterinary Medicine 70:133-152.

Fordham, D., A. Georges, B. Corey, and B. W. Brook. 2006. Feral pig predation threatens the indigenous harvest and local persistence of snakenecked turtles in northern Australia. Biological Conservation 133:379-388.
Gabor, T. M., E. C. Hellgren, R. A. Bussche, and N. J. Silvy. 1999. Demography, sociospatial behaviour and genetics of feral pigs (Sus scrofa) in a semi-arid environment. Journal of Zoology 247:311-322.

Hahn, E., G. Page, P. Hahn, K. Gillis, C. Romero, J. Annelli, and E. Gibbs. 1997. Mechanisms of transmission of Aujeszky's disease virus originating from feral swine in the USA. Veterinary Microbiology 55:123-130.

Hone, J. 1995. Spatial and temporal aspects of vertebrate pest damage with emphasis on feral pigs. Journal of Applied Ecology 32:311-319.

Hone, J. 2002. Feral pigs in Namadgi National Park, Australia: dynamics, impacts and management. Biological Conservation 105:231-242.

Hone, J., and R. Kleba. 1984. The toxicity and acceptability of warfarin and 1080 poison to penned feral pigs. Wildlife Research 11:103-111.

Institute of Medical and Veterinary Science. 2010. Assessing the humaneness and efficacy of a new feral pig bait in domestic pigs. Report for the Australian Government Department of the Environment, Water, Heritage and the Arts. Canberra, Australia. <http://www.environment. gov.au/system/files/resources/091b0583-f35c-40b3-a530-f2e0c307a20c/ files/pigs-imvs-report.pdf $>$. Accessed 09 May 2016.

Ivan, J. S., and E. S. Newkirk. 2015. CPW Photo Warehouse: a custom database to facilitate archiving, identifying, summarizing and managing photo data collected from camera traps. Methods in Ecology and Evolution 7:499-504.

Jolley, D. B., S. S. Ditchkoff, B. D. Sparklin, L. B. Hanson, M. S. Mitchell, and J. B. Grand. 2010. Estimate of herpetofauna depredation by a population of wild pigs. Journal of Mammalogy 91:519-524.

Keiter, D. A., J. J. Mayer, and J. C. Beasley. 2016. What is in a "common" name? A call for consistent terminology for nonnative Sus scrofa. Wildlife Society Bulletin 40:384-387.

Lapidge, S., J. Wishart, M. Smith, and L. Staples. 2009. Is America ready for a humane feral pig toxicant. Pages 49-59 in J. R. Boulanger, editor. Proceedings of the 13th Wildlife Damage Management Conference, Ithaca, New York, USA.

Lapidge, S., J. Wishart, L. Staples, K. Fagerstone, T. Campbell, and J. Eisemann. 2012. Development of a feral swine toxic bait (Hog-Gone ${ }^{\mathrm{si}}$ ) and bait hopper (Hog-Hopper $\left.{ }^{\mathrm{TM}}\right)$ in Australia and the USA. Pages 19-24 in S. N. Frey, editor. Proceedings of the 14th Wildlife Damage Management Conference, Nebraska City, Nebraska, USA.

Leary, S., W. Underwood, R. Anthony, S. Cartner, D. Corey, T. Grandin, C. B. Greenacre, S. Gwaltney-Bran, M. A. McCrackin, R. Meyer, D. Miller, J. Shearer, and R. Yanong. 2013. AVMA guidelines for the euthanasia of animals: 2013 edition. American Veterinary Medical Association, Schaumburg, Illinois, USA.

Matschke, G. H. 1967. Aging European wild hogs by dentition. Journal of Wildlife Management 31:109-113.

Mayer, J. J. 2009. Wild pig behavior. Pages 77-104 in J. Mayer, and I. L. Brisbin Jr., editors. Wild pigs biology, damage, control, techniques, and management. Savannah River National Laboratory, Aiken, South Carolina, USA.

Mayer, J. J., and I. L. Brisbin, editors. 2009. Wild pigs: biology, damage, control techniques and management. Savannah River National Laboratory, SRNL-RP-2009-00869, Aiken, South Carolina, USA.

O'Brien, P. H. 1986. An approach to the design of target-specific vertebrate pest control systems. Proceedings of the 12th Vertebrate Pest Conference 12:247-252.

O'Brien, P. H. 1988. The toxicity of sodium monofluoroacetate (Compound 1080) to captive feral pigs, Sus scrofa. Wildlife Research 15:163-170.

O'Brien, P. H., and B. S. Lukins. 1990. Comparative dose-response relationships and acceptability of warfarin, brodifacoum and phosphorus to feral pigs. Australian Wildlife Research 17:101-112.

Pimentel, D. 2007. Environmental and economic costs of vertebrate species invasions into the United States. Pages 2-8 in G.W.Witmer, W. C. Pitt, and K. A. Fagerstone, editors. Managing vertebrate invasive species: proceedings of an international symposium. U.S. Department of Agriculture, Animal and Plant Health Inspection Service, Wildlife Services, National Wildlife Research Center, Fort Collins, Colorado, USA.

Pimentel, D., L. Lach, R. Zuniga, and D. Morrison. 2000. Environmental and economic costs of nonindigenous species in the United States. BioScience 50:53-65.

Porter, S., and T. Kuchel. 2009. Assessing the humaneness and efficacy of a new feral pig bait in domestic pigs. Unpublished Study: PC0409, Veterinary Services Division, Institute of Medical and Veterinary Science, Canberra, NSW, Australia. 
Seward, N. W., K. C. VerCauteren, G. W. Witmer, and R. M. Engeman. 2004. Feral swine impacts on agriculture and the environment. Sheep \& Goat Research Journal 19:34-40.

Shapiro, L., C. Eason, C. Bunt, S. Hix, P. Aylett, and D. MacMorran. 2016. Efficacy of encapsulated sodium nitrite as a new tool for feral pig management. Journal of Pest Science 89:489-495.

Snow, N. P., J. M. Halseth, M. J. Lavelle, T. E. Hanson, C. R. Blass, J. A. Foster, S. T. Humphrys, L. D. Staples, D. G. Hewitt, and K. C. VerCauteren. 2016. Bait preference of free-ranging feral swine for delivery of a novel toxicant. PLoS ONE 11:e0146712.

Snow, N. P., M. A. Jarzyna, and K. C. VerCauteren. 2017. Interpreting and predicting the spread of invasive wild pigs. Journal of Applied Ecology https://doi.org/10.1111/ 1365-2664.12866

Spencer, P. B., and J. O. Hampton. 2005. Illegal translocation and genetic structure of feral pigs in Western Australia. Journal of Wildlife Management 69:377-384.
Sweeney, J. R., J. M. Sweeney, and S. W. Sweeney. 2003. Feral hog. Sus scrofa. Pages 1164-1176 in G. A. Feldhamer, B. C. Thompson, and J. A. Chapman, editors. Wild mammals of North America: biology, management, and conservation. Johns Hopkins University Press, Baltimore, Maryland, USA.

Taylor, R. B., and E. C. Hellgren. 1997. Diet of feral hogs in the western South Texas Plains. Southwestern Naturalist 42:33-39.

van Riper, C., and J. Scott. 2001. Limiting factors affecting Hawaiian native birds. Studies in Avian Biology 22:221-233.

West, B. C., A. L. Cooper, and J. B. Armstrong. 2009. Managing wild pigs: a technical guide. Volume 1. Jack H. Berryman Institute, Department of Wildland Resources Utah State University, Logan, USA.

West, P. 2008. Assessing invasive animals in Australia 2008. National Land \& Water Resources Audit, Canberra, Australia. <www.nlwra.gov.au>. Accessed 23 May 2016.

Associate Editor: Messmer. 